\title{
Is It Possible to Examine the Suicide Phenomenon from A Social and Economic Perspective?
}

\author{
Volkan ÖNGEL (https://orcid.org/0000-0001-8881-2465), Beykent University, Turkey; \\ volkanongel@beykent.edu.tr \\ Ayşe GÜNSEL (https://orcid.org/0000-0002-4427-7322), Kocaeli University, Turkey; agnsel@ gmail.com \\ Gözde BOZKURT (https://orcid.org/0000-0001-8413-1099), Beykent University, Turkey; \\ gozdebozkurt@beykent.edu.tr
}

\section{İntihar Olgusunu Sosyal ve Ekonomik Açıdan İncelemek Mümkün Mü?}

\begin{abstract}
Suicidal behaviour, like other human behaviours, is a result of socioeconomic and psychological conditions. The research, it is aimed to examine the relationship between socioeconomic factors such as economic income levels, social status and quality of life, and suicidal behaviour in comparison with classical and Bayesian negative binomial regression models. The findings showed that suicidal behaviour increased due to the decrease in economic status and inequality of income distribution among young people. At the same time, it has been determined that employment and divorce rates reduce suicidal behaviour. As a result, it was determined that social and economic factors affected suicidal behaviour in the 15-24 age group, and solutions were suggested.

Keywords $\quad$ : Suicide Case, Bayesian Analysis, Social and Economic Factors.

JEL Classification Codes : $\quad \mathrm{C} 11, \mathrm{O} 12, \mathrm{~J} 13$.

\section{$\ddot{\mathbf{O z}}$}

İntihar davranışı tıpkı diğer insan davranışları gibi psikolojik olduğu kadar sosyoekonomik koşulların da bir sonucudur. Araştırmada, ekonomik gelir düzeyleri, sosyal statü ve yaşam kalitesi gibi sosyoekonomik faktörler ile intihar davranışı arasındaki ilişkinin klasik ve bayes tipi negatif binom regresyon modelleriyle karşılaştırmalı olarak incelenmesi hedeflenmektedir. Bulgular, gençlerdeki ekonomik durum düşüşüne ve gelir dağılımı adaletsizliğine bağlı olarak intihar davranışını arttığını göstermiştir. Aynı zamanda istihdam ve boşanma oranının da intihar davranışını azalttığı tespit edilmiştir. Sonucunda, 15-24 yaş grubundaki intihar davranışının sosyal ve ekonomik faktörlerden etkilendiği belirlenerek çözüm önerilerinde bulunulmuştur.
\end{abstract}

Anahtar Sözcükler $\quad$ : İntihar Vakası, Bayesyen Analiz, Sosyal ve Ekonomik Faktörler. 
Öngel, V. \& A. Günsel \& G. Bozkurt (2022), "Is It Possible to Examine the Suicide

Phenomenon from A Social and Economic Perspective?", Sosyoekonomi, 30(51), 137-148.

\section{Introduction}

The suicide phenomenon, as a cause of death, is described as a health problem both individually and socially, this phenomenon, sociology, psychology, psychiatry, etc. Many disciplines handle it. Suicide, which is among the preventable causes of death, is behaviour individuals perform to end their lives for many reasons. According to Durkheim, who argued suicide as a social phenomenon and carried out the first comprehensive research on suicide in this field, expressed that "every death event that is a direct or indirect result of a positive or negative action by the deceased will result in death" (Durkheim, 2002: 25). Explaining and addressing the cause of suicide with just psychological factors is an unscientific understanding (Tatlılığlu, 2012: 141) since suicide is a complex phenomenon due to its complex nature, resulting from many factors, such as religious, cultural, socioeconomic, sociological, biological, etc. (Taşdelen, 2006: 34). Indeed, in the last century, the suicidal behaviour itself and its antecedents have been examined within many disciplines, for instance, psychiatry, psychology, medicine, and sociology (Şevik et al., 2012: 219). However, due to this complex nature, interdisciplinary studies are required.

According to Durkheim, suicide statistics tend to increase in economic crisis and economic prosperity. He explained this increase as an individual response to uncertainty and change. This uncertainty and rapid economic change lead individuals to irregularity (Durkheim, 2002: 25). Therefore, Durkheim stated that social antecedents of suicidal behaviour could be found. He tried to prove the argument that social factors should be examined, instead of mental illnesses, as reasons for suicide (İnce, 2007: 34). Based on that argument, it is possible to say that social and economic factors are important determinants of suicidal behaviours. Based on official statistics, characteristics such as a low level of education and suffering from unfavourable economic conditions may cause individuals to commit suicide-Turkey from those conditions. The increasing trend in suicide rates over the years makes it necessary to examine the antecedents of suicidal behaviour essential from a sociological perspective. The young population is among the essential dynamics of a country's economic and social development. In the formation of human capital, the population and the gender structure, and age status are considered. Human capital is more dynamic and broader in a country with a younger population. However, losses occur due to not properly using the young population's potential. Since young people cannot take part in both education and employment in a productive manner, there is a possibility that this potential of young people, who play a role in the development of the country, will not be fully used in Turkey, which is among the developing countries (Kılıç, 2014: 121). Both educators and pedagogues claim that one of the biggest problems in Turkey is the youth (Baş, 2017: 150).

Suicidal behaviour, which occurs in all age groups, is more common, especially among young people (O'conner \& Sheehy, 1997: 242). Suicide cases, which are considered an exception in the past, have an increasing trend in recent years in Turkey. Considering the findings of the survey conducted in Turkey, Sahin and Batıün (2003: 29) argue that the 
suicide rates steadily increase in the 15-24 age group. According to the Turkey Statistical Institute, it is possible to analyse the data by age groups through suicide statistics.

Table: 1

Suicide Statistics by Age Group in Turkey (2005-2019 Period)

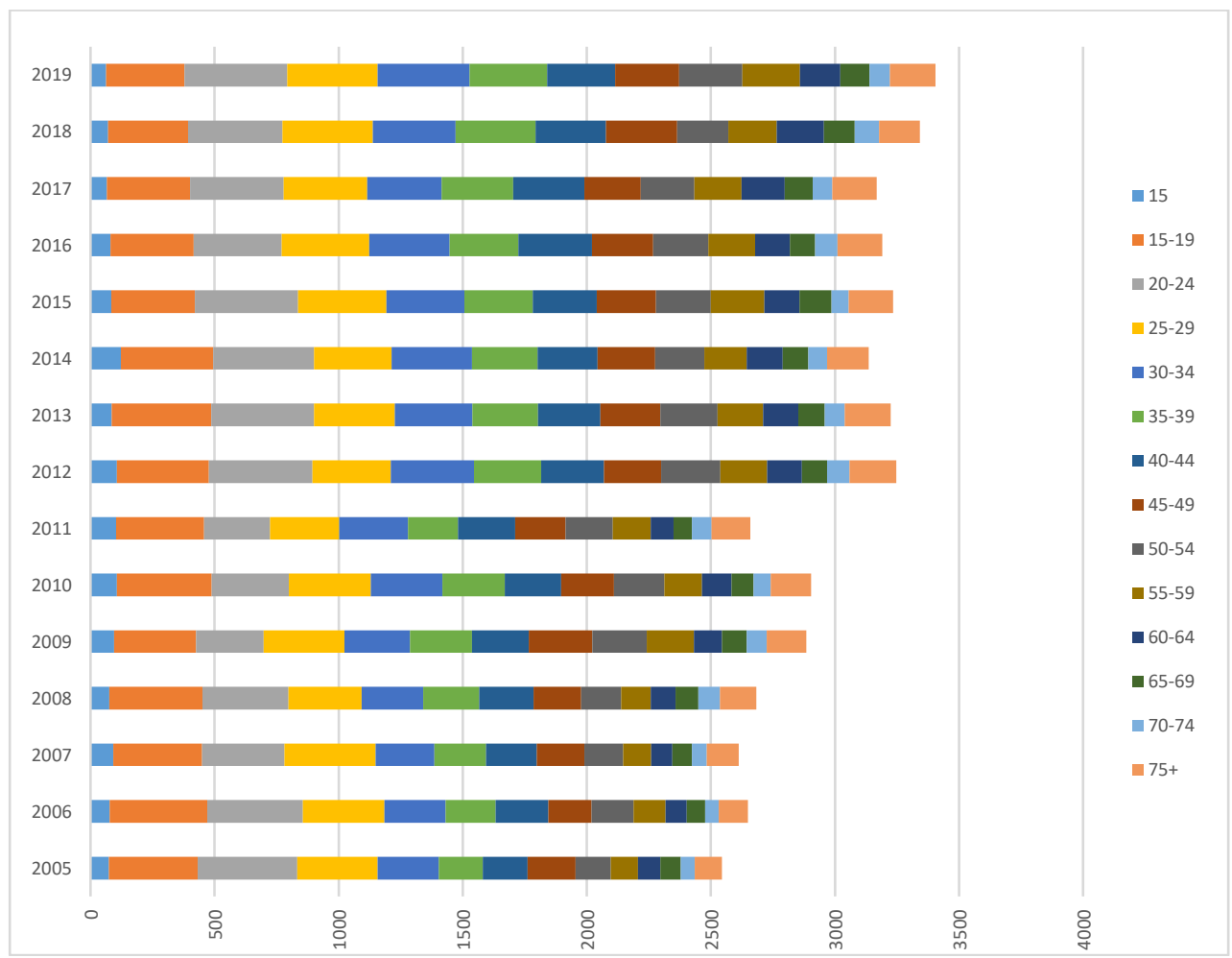

Source: TURKSTAT, <https://tuikweb.tuik.gov.tr/>, 02.04.2021.

As seen in Table 1, between 2005 to 2019, suicide cases most frequently occurred in the 15-24 age group in Turkey. In the world and Turkey, young people between the ages of 15-24 are considered risky in terms of suicide (Atay et al., 2012: 2). At this point, feeling safe, which occurs in societies where economic stability is achieved, gains importance in determining the limits of individual behaviour (Bozkurt, 2012: 25-26). Socioeconomic disadvantages have been considered critical determinants of suicide in time and social classes. The suicide rates tend to increase in low socioeconomic situations. This situation can be expressed as a perception of gain at the personal level. The suicide rate increases, especially in socioeconomic fluctuations and economic crises (Kübalı, 2007: 35-36). Depending on social cohesion and social structure, suicide rates vary between countries. According to the egoistic suicide phenomenon, the possibility of suicide increases in cases where social interaction is minor and family ties are weak. 
On the other hand, the anomic suicide phenomenon argues that the possibility of suicide increases in economic and social crises in society. Europe in both world wars can be given as an example of this situation. Suicide rates increased more in those periods in Europe than in other times of history. In Turkey, social events such as child marriages, domestic violence, and cheating increase the likelihood of suicide. Moreover, the extant literature shows that the suicide rates of women are lower than men in societies in which divorce is not prohibited. At the same time, it is higher than men in other societies where divorce is not permitted (Tatlılığlu, 2012: 143). In this study, the antecedents of suicide, which have been investigated from many different angles in the extant literature, were examined from a socioeconomic perspective. The expected relationships between suicidal behaviour and socioeconomic variables are given in Table 2.

Table: 2

\section{Expected Relationships Between Suicidal Behaviour and Socioeconomic Variables}

\begin{tabular}{|c|c|}
\hline Variables & Expected Relationship \\
\hline Gini Coefficient & + \\
\hline Rough Divorce Rate &,+- \\
\hline Poverty Rate & + \\
\hline Employment Number & - \\
\hline
\end{tabular}

Source: Compiled by the author.

Accordingly, this study examines Turkey's socioeconomic factors (Table 2) associated with suicidal behaviour via classical and Bayesian Poisson regression approaches. Indeed, the phenomenon of suicide has been the subject of sociology and philosophy throughout human history. For this reason, it is essential to predict the risk of suicide, develop appropriate methods, and take precautions. This study, in which statistical evaluations are carried out, tries to fill the interdisciplinary gap by contributing to social sciences on suicide.

\section{Literature Review}

According to Durkheim, who conducted the first comprehensive study investigating suicidal behaviour, suicides are "preventable as long as the individuals integrate with the society" (Durkheim, 1992: 34). Durkheim examined and systematized 26,000 suicide files in his study. Based on those data, he stated that there is a tendency to commit suicide. Even though Durkheim argued that psychological illnesses might also be related to suicide behaviour, he could provide empirical evidence regarding the relationship between suicide cases and mental illnesses. Drawing attention to his social reformer identity, Durkheim stated that the primary causes of suicide are sociological instead of psychological. According to social theory, the functioning of society should be examined, such as social welfare, economy, religion, and family, which are defined as social phenomena. For this reason, studies that include poverty suicide are examined.

Tel and Uzun (2003) examined the social support levels of patients who came to the emergency department to commit suicide between January 01 and March 31, 2002. As a result, they found out that those mainly were having difficulty coping with stress and having 
Öngel, V. \& A. Günsel \& G. Bozkurt (2022), "Is It Possible to Examine the Suicide Phenomenon from A Social and Economic Perspective?", Sosyoekonomi, 30(51), 137-148.

a moderate level of social support. Also, it was stated that they concluded that the age group in which suicide cases occur frequently is 15-19 (Tel \& Uzun, 2003: 158). Acar (2009), in his study examining the suicide cases within emergency services, stated that those, who applied to the emergency department with a suicide case, were single primarily (Acar, 2009: 58). Gür (2012), in another study on emergency departments, found that most of those who attempted suicide were women and under 30 years old. Rodriguez-Andres et al. (2011) investigated the socioeconomic factors affecting suicidal behaviour in Japan for men, women and total suicide cases between 1957-2009 separately. As a result, they discovered that the most crucial reason for suicide in males was divorce, while fertility problems came forward in females. They also stated that unemployment and economic difficulties had a similar effect on both genders. As a result, they concluded that sociological factors were more significant than the economic ones on committing suicide in Japan (Rodriguez-Andres et al., 2011: 730). Ayla et al. (2018) investigated the interrelationships between suicide, divorce, and marriage between 1980 and 2016, within the framework of the economic crisis. They found that the problem of the near past ( 3 and 4 years ago) increased suicidal rates of today. For this reason, they stated that all the steps to be taken against the crisis should be expanded before and after the crisis (Ayla et al., 2018: 432).

Gerdtham and Johannesson (2003) studied approximately 30,000 people between 24 and 65 years old in Sweden. Their findings revealed that unemployment was a significant antecedent of suicidal behaviour, and it increased the risk of death ratio due to suicide by approximately 50\% (Gerdtham \& Johannesson, 2003: 506). In another study examining the relationship between suicide and unemployment, Blakely et al. (2003) investigated 2.04 million people between 18-64 in New Zealand. They found a strong relationship between suicide rates and unemployment (Blakely et al., 2003: 594). In addition, Tunalı and Özkaya (2016) examined the relationship between unemployment ratios and suicidal behaviour during 1980-2014. As a result of the study, a bilateral causality between unemployment and suicide has been exposed. According to them, 26\% of the suicide cases occurred due to commercial failures in the crisis periods (Tunalı \& Özkaya, 2016: 68). Varol and Karagoz (2020) investigated the relationship between suicide ratios and socioeconomic factors. Unemployment, divorce, per capita income, alcohol consumption, labour force participation, urbanization, and inflation were the most important antecedents of suicidal behaviour, although they vary by gender (Varol \& Karagöz, 2020: 278).

\section{Data and Methodology}

The socioeconomic variables to be analysed were obtained from the TURKSTAT database for the study. The variables were determined according to the relevant literature on the suicide case. They thought to affect are the number of suicides in the 15-24 age group, the poverty rate, the employment rate, the gross divorce rate, and the Gini coefficient. Data related to completed suicides in Turkey were collected systematically by TURKSTAT after 2005. For this reason, the relevant variables were examined in the period between 20062019. 
Data analysis was carried out using the Poisson regression model since the dependent variable was count data. Counting data consists of positive values and generally does not reveal a standard distribution feature. In a study where counting data is used, biased parameter estimators can be encountered if the linear regression method is used. For this reason, methods that take into account the original distribution of the data should be preferred. Stata 15 computer program was used in data analysis.

\section{Results}

The classical Poisson regression propagation parameter established with variables was calculated as 2.61. It was determined that the data showed excessive spread due to being more significant than 1. Statistically, as a result of the goodness-of-fit test used as a goodness of fit test, it was seen that the model was not suitable for poisons (p-value: $0.000<0.05$ ). Therefore, negative binomial and generalized Poisson models were also estimated, in which excessive propagation was taken into account. Since the spread parameter of the generalized negative binomial regression model was obtained almost zero, it was concluded that the use of the model was not appropriate. In the negative binomial model, since the propagation parameter is a value other than zero, it was seen that the data fit the model. Three iterations estimated the model, and the Akaike information criterion was 163.31, Bayes information criterion was 167.14 , and log-likelihood value was -77.03 . The tests performed to examine the assumption of normality in the negative binomial model are given in Table 3.

Table: 3

\section{Normality Tests Results}

\begin{tabular}{|c|c|c|c|c|}
\hline \multicolumn{5}{|c|}{$\begin{array}{c}H_{0}: \text { There is conformity to Normal Distribution. } \\
H_{a}: \text { There is no compliance with Normal Distribution. }\end{array}$} \\
\hline $\begin{array}{ll}\text { Variables } & \text { Tests }\end{array}$ & Skewness and Kurtosis Test & Shapiro-Wilk Test & Doornik-Hansen Test & Classic Mahalanobis Criterion $\left(X^{2}\right)$ \\
\hline Suicide Count & 0.7790 & 0.69505 & & .053585 \\
\hline Poverty Rate & 0.1444 & 0.33299 & & .125631 \\
\hline Gini Coefficient & 0.2511 & 0.24102 & & .632418 \\
\hline Employment Rate & 0.8528 & 0.94000 & & .543721 \\
\hline Rough Divorce Rate & 0.7912 & 0.24819 & 0.8217 & $\begin{array}{l}.789476 \\
.923773 \\
.897513 \\
.913705 \\
.531925 \\
.600984 \\
.633485 \\
.306611 \\
.331822 \\
.147675\end{array}$ \\
\hline
\end{tabular}

As a result of comparing the test results given in Table 3, according to the 5\% margin of error, it is seen that the primary hypothesis cannot be rejected. In addition, the probability values of Mahalanobis scores related to the observations were calculated and given $(\mathrm{p}<.5)$. Looking at the obtained values, no problem was detected in the distance of any data point from the mean of the predicted variables. When the predicted models were evaluated in general, it was seen that the use of the classical Poisson model was not appropriate due to the excessive spread. It was concluded that the generalized negative binomial model is not 
suitable for use due to the propagation parameter. The negative binomial model was appropriate for determining the suicide case. However, in these models, the dependent variable is generally expected to be suitable for the negative binomial distribution. If the dependent variable belongs to a different distribution family, it may not benefit.

For this reason, Bayesian Poisson regression models were estimated, which allow for use in the absence and presence of information about a priori distribution. Bayesian estimates of all the models estimated above were performed, respectively. It was seen that the variables belonging to the models were obtained the same as in the classical models. In these models, the a priori and posterior distribution is estimated to be suitable for multiple normal distributions. The deviation information criterion, expressed as DIC, is used when the posterior distribution of the model is approximately multivariate normal, resulting from obtaining the posterior distributions of the models in the Bayesian model selections by Markov chain Monte Carlo (MCMC) simulation. Since the Akaike information criterion (AIC) has an asymptotic approach, it has been determined that the Bayesian negative binomial model with the highest value is also the most suitable model according to this criterion. However, in the absence of a priori information for the model, the Jeffreys method was also used for the three models mentioned. The Jeffreys, a priori distribution allows obtaining an information-free a priori distribution for any parametric model. According to the appropriate Jeffreys, the models estimated a priori distributions obtained for the different distributions of the observations were compared.

Table: 4

Information Criteria for Bayesian Regression Estimates

\begin{tabular}{|l|c|c|}
\hline Models Criterias & Log(ML) & DIC \\
\hline Negative Binomial & -127.7345 & 188.8925 \\
\hline Generalized Negative Binomial & -114.7324 & 166.6163 \\
\hline
\end{tabular}

As seen in Table 4, it is seen that the most suitable model whose a priori distribution is determined by Jeffreys method according to the information criteria is the Bayesian negative binomial model. However, in cases where the a priori distribution is unknown, the a priori distribution is determined by the multiple normal distributions in the Jeffreys method to ensure that the regression models provide the assumptions. The posterior is also offered to fit the numerous normal distributions. The Bayesian information criteria of the models are also expected to be suitable for multiple normal distributions due to their asymptotic characteristics. In both cases where the a priori distribution was normal and determined according to Jeffreys, it was observed that the model results were obtained very close to each other, and information criteria were obtained close to each other. However, to determine which distribution or distributions are suitable for the data, the distribution determination process was performed through the EasyFit 5.6 program. As a result of examining the suicide numbers data, it was determined that the distribution is right-skewed. Therefore, as a result of the examination made to determine the a priori distribution of the model, it was seen that it is suitable for the Beta distribution. The results of the distribution are given in Table 5 . 
Table: 5

Distribution Conformity Results

\begin{tabular}{|l|c|c|}
\hline Distribution & Kolmogorov-Smirnov & Chi-Square \\
\hline Beta & $\begin{array}{c}0,5423 \\
\left(\begin{array}{l}\alpha=1,2012 \\
\beta=1,0174\end{array}\right)\end{array}$ & $\begin{array}{c}0,5929 \\
\text { (rank: 36) }\end{array}$ \\
\hline
\end{tabular}

As seen in Table 5, it is seen that the use of Beta distribution among statistical distributions according to each of the tests is appropriate. Bayesian negative binomial regression estimation results where the a priori distribution is beta distribution are given in Table 6.

Table: 6

Bayesian Negative Binomial Regression Estimation Results with an A priori Distribution of Beta

\begin{tabular}{|c|c|c|c|c|c|c|}
\hline \multirow{2}{*}{ Independent Variables Values } & \multirow{2}{*}{ Mean } & \multirow{2}{*}{ Standard Error } & \multirow{2}{*}{ MCSE } & \multicolumn{2}{|c|}{ Reliable Range (\%95) } & \multirow{2}{*}{ Median } \\
\hline & & & & Lower Bound & Upper Bound & \\
\hline Poverty Rate & 0.118 & 0.056 & 0.010 & 0.003 & 0.235 & 0.120 \\
\hline Rough Divorce Rate & 0.472 & 0.220 & 0.043 & 0.032 & 0.904 & 0.488 \\
\hline Gini Coefficient & 0.306 & 1.021 & 0.271 & -1.384 & 2.527 & 0.217 \\
\hline Employment Rate & -0.023 & 0.015 & 0.001 & -0.054 & 0.006 & -0.023 \\
\hline Constant Term & 4.987 & 1.037 & 0.238 & 2.880 & 6.996 & 4.946 \\
\hline $\ln \alpha$ & -4.711 & 0.592 & 0.029 & -4.731 & -5.805 & -3.462 \\
\hline & & $\begin{array}{r}\text { Number of M } \\
\text { MCMC s } \\
\text { Efficie }\end{array}$ & $\begin{array}{l}\text { terations } \\
\text { size: } 10 \text {, } \\
\text { in: } 0.001 \\
0032 \\
0073\end{array}$ & & & \\
\hline
\end{tabular}

Since the a priori distribution of the model whose estimation results are given in Table 6 is beta distribution, the posterior distribution is also used as beta due to the information from the conjugate distribution families in informational situations. A comparison was made between the Bayesian negative binomial regression determined by the Jeffreys method used in cases where the a priori distribution was unknown and the models in which the a priori distribution was defined as beta. It was decided that using the Bayesian negative binomial regression model is more appropriate because it has more minimal criteria. The minor knowledge criterion of this model is thought to be because the dependent variable used in negative binomial regression generally conforms to the Poisson or normal distribution in practice. Therefore, the efficiency criterion of the model estimated according to the Jeffreys method is given in Table 7. 
Table: 7

Effectiveness Summary of the Negative Binomial Model with A priori Distribution of the Jeffreys Method

\begin{tabular}{|l|c|}
\hline Variables & Criteria \\
\hline Rough Divorce Rate & Activity Value \\
\hline Poverty Rate & 0.0329 \\
\hline Gini Coefficient & 0.0455 \\
\hline Employment Rate & 0.0472 \\
\hline Constant Term & 0.0393 \\
\hline $\ln \alpha$ & 0.0386 \\
\hline$\sigma^{2}$ & 0.0584 \\
\hline
\end{tabular}

As can be seen in Table 7, it is seen that the activity value calculated for the variance and the efficiency values of the variables in the model are very close to each other. For this reason, it has been concluded that the model is generally effective and can be evaluated. In this study, the criteria of AIC and the asymptotic form of this criterion, DIC, were compared between the two approaches. The Bayesian approach was preferred because the Bayesian negative binomial regression has a lower information criterion value. At the same time, another important reason is the necessity of the Poisson distribution of the dependent variable in the classical Poisson regression method. The Bayesian approach was preferred in this study because it counted data, but its distribution can be differentiated.

The relative risk ratios of the model estimated in Table 6 are examined. While other variables are fixed, the average number of suicides is 248,044 . The increase in the poverty rate causes a 1,127-fold increase in suicides. The increase in crude divorce rate causes a 1,642-fold increase in suicides. The increase in the Gini coefficient causes a 2.39-fold increase in suicides. The increase in employed individuals causes a 0.976 -fold decrease in suicides. In both approaches, it was observed that the coefficients and the marginal effects of the coefficients were obtained very close to each other. However, since the simulation process is carried out in the Bayesian regression estimation and has an iterative process, it can give different results, albeit close to each other, in each estimation process. Therefore, coefficient estimators can give deviating results. It is seen that the reliable Range of the coefficients estimated by the Bayesian method is more comprehensive than in the classical approach. This is because the standard errors of the coefficients estimated by the Bayesian method are more minor. If a decision is made between both approaches, the DIC criterion, $\mathrm{AIC}$ in the classical approach and AIC in the Bayesian approach, can be evaluated. However, in the Bayesian approach, since the standard errors are obtained smaller due to the iteration process, the information criteria are obtained at a minimum compared to the classical approach. Therefore, it seems more likely to choose the model estimated by the Bayesian approach.

\section{Conclusion}

This study tried to determine the socioeconomic factors related to suicidal behaviour by classical and Bayesian regression approaches. Considering the hypothesis tests and knowledge criteria, the most suitable model for both approaches is the negative binomial 
regression model. The extant literature shows that the Bayesian estimation method can give more effective parameter estimation when the assumptions are not met in regression types, such as linear regression, Poisson regression, etc. However, when the premises are met and there is no prior knowledge, the classical approach seems more appropriate in obtaining parameter estimators without deviation. In determining the preliminary distribution of Bayesian models, i) pre-distribution that reflects the knowledge of the researcher or the expert, and ii) the preliminary information coming from the theory depends entirely on the application's content. For example, if there is social relationship modelling, a predistribution can be determined using the survey technique based on the survey results. Suppose the mentioned example is to be expressed for this study. In that case, it will be possible to estimate the model's parameters, established in line with the questionnaire results, by surveying individuals who apply to emergency service for committing suicide for an uncertain pre-distribution. As a result of the estimation of this model, the findings can be considered preliminary information. This model, involving preliminary information and distribution of similarity, and the general model that examines the case of suicide will be integrated. The final allocation will be formed, and the parameters can be estimated. In this study, the Bayesian approach was considered more appropriate, based on the possibility of not providing the assumption of the dependent variable in the classical approach. As the predistribution is known, a Bayesian approach is beneficial in health and natural science research. According to the estimated model result, the relevant theory obtained the effect of the examined variables on the number of suicides.

We observed that the number of suicides increased due to the decline in individuals' economic status. In contrast, the number of suicides decreased with increased employment rates. We also witnessed that an increase in the Gini coefficient, which expresses the state of justice in the income distribution of individuals, leads to increases in the number of suicides. The findings are supported by studies examining economic factors in the suicide literature (Rodriguez-Andres et al., 2011; Ayla et al., 2018; Gerdtham \& Johannesson, 2003; Tunalı \& Özkaya, 2016; Blakely et al., 2003). In addition, we observed that the increase in the rate of gross divorce decreased the number of suicides. The findings are supported by studies examining sociological factors in the suicide literature (Varol \& Karagöz, 2020; Acar, 2009). When the results were evaluated in general, it was determined that suicidal behaviour in the 15-24 age group -young people- was affected by social and economic factors.

During the youth period, difficulties arise for policymakers, as psychological, biological, and sociological factors bring problems, and those factors are transient. Significantly, the acceleration of communication improves the relations of individuals and societies with today's technology. Young individuals have the opportunity to share their expectations, wishes, and opinions. This extended communication further improves the qualities of young individuals based on their psychological and physiological characteristics. The concentration of the young population in developing countries results in some problems either. At this point, reducing risks with an understanding based on social support is also essential. Although the necessity of a holistic approach has been confirmed in line with the 
findings obtained from the study, the existence of many variables makes it difficult to examine this complex issue holistically. Thus, non-governmental organizations and official authorities must adopt the aim of alleviating suicidal tendencies. It is necessary to target the total population in general and the high-risk groups. According to Durkheim, although suicide has always been existed in human life, in modern societies, suicides increase pathologically. Due to the lack of social regulations and social integration (Ritzer \& Stepnisky, 2014: 98). When the reasons for the suicide of young people in the 15-35 age group are examined, both individual and social protection measures will indeed have positive reflections in defeating this problem (Küpçük et al., 2004: 7). The findings of this study supported this argument. To demonstrate more realistic interdisciplinary suicide, cases of suicide should be examined, and solutions should be developed without traditional or modern prejudices.

To increase the life quality of young people, necessary steps should be taken in areas such as increasing access to social and economic opportunities, preventing discrimination, protecting participation rights, and providing employment opportunities. As a result of the increase in life quality, social development will also be positively affected. Due to the rise in the rate of the young workforce, economic growth and development will proceed either. Active, participatory, skilled youth should gain more attention, particularly in developed countries, transforming into an information society. We think that developing programs that enable young people to adapt to social life and support programs is essential. It is necessary to create flexible models that are handled from different aspects, such as acquiring basic life and occupational skills, poverty alleviation programs, and ensuring a fair income distribution. In particular, the inequality of income distribution and poverty are fundamental problems that await a solution among Turkey's many unsolved socioeconomic issues. This situation experienced by young people, who are more at risk of being exposed to the adverse effects of poverty than adults, negatively impacts both individuals and society. Thus, spreading the policies towards young people in the inferior parts of society, regulating income distribution problems, and eliminating social inequality is required. We saw that the theories about suicide, a highly complex phenomenon, usually explain just one aspect. However, this study revealed that the individual should be examined with a holistic model. Internal and external factors such as biological, psychological, and social factors are evaluated together in explaining suicidal behaviour.

\section{References}

Acar, A. (2009), “Acil Servise Gelen İntihar Vakalarının Sosyodemografik Açıdan İncelenmesi”, Yüksek Lisans Tezi, İstanbul: Marmara Üniversitesi Sağl1k Bilimleri Enstitüsü.

Atay, İ.M. et al. (2012), "Suicide Attempt, Prevalence of Death Thoughts and Risk Factors in Isparta City Center", Turkish Journal of Psychiatry, 23, 1-10.

Ayla, D. et al. (2019), "Social Impact of the Economic Crisis: An Application on Turkey (19802016)", Atatürk University Journal of Economic and Administrative Sciences, 33(2), 415-434. 
Baş, H. (2017), "Bir Sosyal Belediyecilik Uygulaması Olarak İstanbul Esenler Belediyesi Gençlik Merkezi Örneği”, AIBBÜ Sosyal Bilimler Enstitü Dergisi, 17(1), 150.

Batıgün, A.D. \& N.H. Şahin (2009), "Testing a Model for Determining Suicide Risk in High School and University Students", Turkish Journal of Psychiatry, 20(1), 28-36.

Blakely, T. et al. (2003), "Unemployment and Suicide Evidence for A Causal Association?", Epidemiol Community Health, 57(8), 594-600.

Bozkurt, V. (2012), Değişen Dünyada Sosyoloji: Temeller, Kavramlar, Kurumlar, İstanbul: Ekin Kitabevi.

Durkheim, E. (2002), Intihar, (Çev.: Ö. Ozankaya), İstanbul: Cem Yayınevi.

İnce, M.A. (2007), “İntihar Din-Psikolojik Bir İnceleme (Van İli Örneği)”, Yüksek Lisans Tezi, Kayseri: Erciyes Üniversitesi Sosyal Bilimler Enstitüsü.

Kübalı, Z. (2007), “Ankara İlinde Bir Kamu Hastanesi Acil Bölümünde İntihar Girişim Vakalarının İncelenmesi”, Yüksek Lisans Tezi, Ankara: Gazi Üniversitesi Sağlık Bilimleri Enstitüsü.

Küpçük, Y. vd. (2004), İntiharın Önlenmesi Birinci Basamak Sağlık Çalışanları İçin Kaynak, (Çev: T. Kurtuluş \& A.T. Demirtaş), Ankara: T.C. Sağlık Bakanlığı TSHGM.

O’Conner, R.C. \& N.P. Sheehy (1997), "Suicide and Gender”, Mortality, 2(3), 239-253.

Ritzer, G. \& J. Stepnisky (2014), Sosyoloji Kuramları, (Çev.: H. Hülür), Ankara: Deki Yayınları.

Rodriguez-Andres, A.R. et al. (2011), "Socioeconomic Determinants of Suicide in Japan", The Journal of Socioeconomics, 40, 723-731.

Şevik, A.E. vd. (2012), “İntihar Girişimlerinin İncelenmesi: Risk Faktörleri ve Takip”, Klinik Psikiyatri, 15, 218-225.

Smirnov, N.V. (1939), "On the Estimation of the Discrepancy Between Empirical Curves of Distribution for Two Independent Samples", Bulletin of Moscow University, 2(2), 3-14.

Taşdelen, M. (2006), “İnanç Açısından İntihar”, Yüksek Lisans Tezi, Konya: Selçuk Üniversitesi Sosyal Bilimler Enstitüsü.

Tatlılığlu, K. (2012), "Sosyal Bir Gerçeklik Olarak İntihar Olgusu: Sosyal Psikolojik Bir Değerlendirme”, AİB̈̈ Sosyal Bilimler Enstitüsü Dergisi, 12(2), 135-157.

Tel, H. \& S. Uzun (2003), "İntihar Girişimi İle Acil Servise Başvuran Hastaların Sosyal Destek ve Stresle Baş Etme Durumları”, Anadolu Psikiyatri Dergisi, 4, 151-158.

Tunalı, H. \& S. Özkaya (2016), “Türkiye'de İşsizlik-İntihar ilişkisinin analizi”, Kırklareli Üniversitesi İktisadi ve İdari Bilimler Dergisi, 5(2), 56-70.

Ulf-G, G. \& M. Johannesson (2003), “A Note on The Effect of Unemployment on Mortality”, Journal of Health Economics, 22(3), 505-518.

Varol, Z. \& K. Karagöz (2020), “Affective Socioeconomic Factors on Suicide in Turkey: An Econometric Analysis”, Manisa Celal Bayar Üniversitesi Sosyal Bilimler Dergisi, TBMM 100. Y11 Özel Sayıs1, 260-280. 